\title{
Early diagnosis of HTLV-1-associated myelopathy (HAM/TSP) in HTLV-1 carrier clinic
}

\author{
Toshio Matsuzaki ${ }^{1}$, Ryuji Kubota', Hiroshi Takashima², Shuji Izumo ${ }^{1 *}$ \\ From 16th International Conference on Human Retroviruses: HTLV and Related Viruses \\ Montreal, Canada. 26-30 June 2013
}

Early diagnosis and medical intervention are important for functional prognosis of HAM/TSP patients. In order to find out patients with early stage of HAM/TSP, we started HTLV-1 carrier clinic in the endemic area, Kagoshima, Japan, in 1999. Till the end of 2012, 407 persons have visited the clinic as first time-visitors of HTLV-1 carriers, and 6 cases were diagnosed as early stage of HAM/TSP. These 6 cases are 1 male and 5 females, 20-55 years old $($ mean $=41.8)$ at the diagnosis, no history of blood transfusion, and 4 cases have family history of HAM/TSP. They could run and had no subjective symptoms on motor function, but all had subjective symptoms either dysesthesia/pain or urinary disturbances. Physical examination demonstrated hyper-reflexes of lower extremities with mild spasticity, positive Babinski signs, and decreased sweating of lower trunk and legs. Laboratory test showed positive anti-HTLV-1 antibodies in both sera and CSF, and proviral loads in the blood were high (386-2181 copies/104 PBMC) in all cases. Two cases were treated with steroids and their urinary disturbances were improved. After 2 years of follow up, their symptoms remained unchanged and decrease of proviral load was obtained in one case. These experiences in HTLV-1 carrier clinic indicate that early diagnosis of HAM/TSP is possible by careful medical checking of HTLV-1-positive individuals. Decrease of sweating in lower body, and hyper-reflexes of legs with typical Babinski sign are important signs for early diagnosis. Treatment intervention at early stage of the disease might improve functional prognosis of HAM/TSP patients.

\section{Authors' details}

'Divisions of Molecular Pathology, Center for Chronic Viral Diseases, Kagoshima University, Japan. ${ }^{2}$ Department of Neurology and Geriatrics, Kagoshima University, Japan.

Published: 7 January 2014

doi:10.1186/1742-4690-11-S1-P29

Cite this article as: Matsuzaki et al.: Early diagnosis of HTLV-1-associated myelopathy (HAM/TSP) in HTLV-1 carrier clinic. Retrovirology 201411 (Suppl 1):P29.
Submit your next manuscript to BioMed Central and take full advantage of:

- Convenient online submission

- Thorough peer review

- No space constraints or color figure charges

- Immediate publication on acceptance

- Inclusion in PubMed, CAS, Scopus and Google Scholar

- Research which is freely available for redistribution
( Biomed Central 